\title{
A STUDY ON THE ACCEPTANCE OF INFORMATION TECHNOLOGIES FROM THE PERSPECTIVES OF THE ACADEMICIANS IN TURKEY
}

\author{
Assoc. Prof. Dr. Ertugrul TARCAN, Akdeniz University, Alanya Faculty of \\ Business, tarcan@akdeniz.edu.tr \\ Assoc. Prof. Dr. Ergin Sait VAROL, Istanbul University, Vocational School of \\ Technical Sciences, varol@istanbul.edu.tr \\ Assist. Prof. Dr. Boran TOKER, Akdeniz University, Alanya Faculty of Business, \\ borantoker@akdeniz.edu.tr
}

\begin{abstract}
Educational institutions have been increasingly started to use information technologies (ITs) for improving the service quality and achieving the effective organizational outputs in a competitive global environment. An individual's intention to use ITs is a crucial factor in determining the success or failure of an information technology (IT) system implementation. This study attempts to investigate the factors affecting the intention to use ITs from the academicians' perspectives in Turkey. This research extends the technology acceptance model (TAM) framework with subjective norm (SN) and facilitating conditions (FC) acting as external variables. The model has been tested using web-based data collected from 510 academicians. The findings demonstrate that this extended TAM can explain $80 \%$ of the variance of intention to use ITs. And also, $\mathrm{SN}$ and FC are potential variables that may be used to extend the TAM for the research on the academicians' intention to use towards ITs. This study reveals that educational managers can use this research model as a helpful tool in better understanding stakeholders' behaviors related to the technology acceptance, and also in the process of IT investment, implementation and renovation.
\end{abstract}

Key Words: Academicians, Educational technology acceptance, Subjective norm, Facilitating conditions, TAM, IT, SEM 


\section{INTRODUCTION}

With increasing global competition, as more tasks involve human-Information Technology (IT) interaction, IT literacy has become a key factor for both occupational and personal successes. Therefore, as we move into such a technology-based society, it is important that experiences with Information Technologies (ITs) are made available for all academicians.

The rapidly growing trend towards use of new information technologies in higher education institutions (Bannan-Ritland et al., 2000 p.39; Bratina et al., 2002 p.7; Wiley, 2001 p.494) has made user acceptance an increasingly critical issue, as the end users are very important for the effective use of the information technologies (Cheney and Dickson, 1982 p.171). Although user acceptance has received fairly extensive attention in prior research, the majority of these studies have focused on specific information systems in Management Information Systems (MIS) fields, other than education. There is scarce research literature that addresses learner intention to use (IU), and acceptance of educational technologies (McMahon et al., 1999 p.303, Mun and Hwang, 2003 p.433). New trend in education such as lifelong learning developed learning and teaching methods, and virtual education supports the studies to be done related to the technology acceptance process. (Martinez-Torres et al., 2008, p.495; Turan and Colakoglu, 2008, p.106-111; Varol et al.,2010, p.91-93).

Information Technology has been a significant research area for some time, but its nature has changed considerably since the over a decade ago. Many researchers have proposed theories and models of technology acceptance in order to explain and predict user acceptance with technology in order to account for rapid change in both technologies and their environments. Each theory or model has been proposed with different sets of determinants. According to the meta-analysis study of Legris et al. (2003, p.191), literature indicates that TAM and its extended variations can explain up to $\% 40$ the variance of IU for the different contexts. It has been thought that a different TAM extended with the new variables may explain the variance of IU at a higher level. Researchers in MIS recently also suggest that factors influencing intention to use Information Systems (IS) may vary, and the degree of influence of the same factors differs with different stages of adoption (Legris et al., 2003 p.200-202, Lu et al. 2005, p.246).

An individual's technology acceptance is a crucial factor in determining the success or failure of a computer systems project. Given that the academician is the key to effective use of information technologies in the university educational system, it is important to understand academicians' IU towards IT and the factors that influence these intentions. The successful use of ITs in academic life will depend largely on subjective norm (SN) and facilitating conditions (FC) of academicians and their willingness to embrace the technology. Literature has points out that $\mathrm{FC}$ and $\mathrm{SN}$ are suitable variables to be used in designing a new extended TAM. Hence, this study extends the technology acceptance model 
(TAM) framework, with SN and FC acting as external variables to be able to answer some questions relating to the acceptance and usage of technology of the academicians in teaching, learning and their academic studies (Davis 1989, p.319 and 1993, p.475).

\section{LITERATURE REVIEW}

\subsection{Factors Effecting Information Technology's Use}

IT at both workplace and at home influences whether an individual user uses the technology. Consequently, there has been enormous investment in building IT infrastructure in order to ensure that there are enough hardware and software resources available in organizations. However, the sole availability of infrastructure does not guarantee actual usage in daily routines. It is also very important to understand key motivational variables in IT use of individual end users. Recent studies find that instructors and students are still reluctant to engage in an active or sustained manner in activities using IT (Reffell and Whitworth, 2002 p.427and434). The actual formal use of IT in undergraduate and graduate studies still remains inconsistent and varies significantly from individual courses to individual institutions (Breen et al., 2001, p.111, 112 and 113; Marriott et al., 2004 p.121-122). At present more studies propose that further research design should extend beyond the technology-based tools as to include a broader range of social factors (Bielaczyc, 2006 p.325; Selwyn, 2007 p.84). Thus, in order to predict and understand academicians' technology use and acceptance a well- defined framework is essential.

The Technology Acceptance Model (TAM) has been the most widely adopted theoretical framework to study technology acceptance. Perceived usefulness (PU) and perceived ease of use (PEOU) are hypothesized to be the fundamental determinants of user acceptance (Davis, 1989 p.330). Legris et al. (2003, p.202) concluded: "TAM is a useful model, but has to be integrated into a broader one which would include variables related to both human and social change processes and to the adoption of the innovation model". Consequently, while we took TAM as the core framework in our study, we also looked for appropriate human and social constructs to be put into the framework in order to provide a better understanding to the exploration of IT acceptance amongst academicians. After reviewing relevant literature, it is found that "Facilitating conditions" (FC) of users and "subjective norm" (SN) of the users' workplace are appropriate constructs to be considered in formulating the composite framework.

\subsection{Technology Acceptance Model}

The foundation of technology acceptance model is based on the theory of reasoned action by Fishbein and Ajzen (1975, p.410, 449, 450, 508 and 509), and the theory of planned behaviour (Ajzen, 1991, p.179, 206 and 207) derived from theory of reasoned action. The theory suggests that a person's belief 
determines his/her attitude toward things. An attitude is a kind of perceived behavioral control, and a high degree of perceived behavioral control will introduce behaviour intention, and result in actual behaviour.

The original technology acceptance model suggests that two beliefs named PU and PEOU are instrumental in explaining the variance in users' intentions. PU is the degree to which a person believes that using a particular system will enhance his or her job performance. PEOU is the degree to which a person believes that using a particular system will be effortless. These factors are common in technology usage settings and can be widely applied to solve the acceptance problem (Taylor and Todd, 1995 p.168-170).

An individual's attitude is hypothesized to influence the behavioral IU a technology, finally relating to actual use. TAM deviated from Theory of Reasoned Action (TRA) from the start, by leaving $\mathrm{SN}$ out of the model. Furthermore, the mediating role of attitude was doubtful. Information systems researchers have investigated the technology acceptance model, and found it to be valid in predicting the individual's acceptance of corporate IT systems (Segars and Grover, 1993, p.521-524; Chin and Todd, 1995 p.244; Doll et. al., 1998 p.855). However, as more and more key motivational determinants were found, the mediating effect of attitude towards behavioral intention to computer technology use diminished.

In the follow-up model Venkatesh and Davis (2000 p.197) proposed an extension, TAM2, which consisted of social influence processes (SN, voluntarism, and images) and cognitive instrumental processes (job relevance, output quality, result demonstrability, and PEOU), but it omitted attitude to use due to weak predictors of behavioral IU. That means the attitude component was not included anymore, and the perceived technology characteristics directly influence the individual's IU the new technology under consideration. Additionally, social influences (operationalized as SN) reentered the model. In a recent review, it was found that nearly half of the studies being reviewed found attitude non significant and did not include attitude in their model framework (Legris et al. 2003 p.200). It seemed that attitude was once actively used but had been excluded from more recent computer technology acceptance studies. However, other models have been proposed as well. Recently, Venkatesh et al. (2003 p.447) integrated eight models of technology acceptance into the Unified Theory of Acceptance and Use of Technology (UTAUT).

We choose to rely on the more traditional and confirmed TAM2 extended by Venkatesh and Davis (2000 p.197) as the basis for our conceptual model. This means we include SN, but exclude attitude. 


\subsection{Facilitating Conditions}

FC related to factors that are present in the environment that exert an influence over a person's desire to perform a task. Conditions and events that create a positive environment for technology adoption such as training and education and organizational technical support can be seen as elements of organizational facilitators (Frambach and Schillewaert, 2002 p.167; Schillewaert et al., 2005 p.325). In their study, Groves and Zemel (2000, p.57) found out that information or materials availability, skills training, and administrative support were estimated as very important factors which influenced the use of instructional technologies in teaching. In another study, faculty members responded to barriers included lack of technical support, lack of adequate software equipment, and lack of faculty administrative support that confronted while participating distance education (Daughtery and Funke, 1998 p.37-38). Also in the other study conducted by Farquhar and Surry (1994 p.22) proposed the adopter's individual factors as influential factors which affect the adoption and utilization of the instructional product. They separated organizational factors into two categories as physical environment and support environment. They gave more important place to support environment that includes the resources and services required in order to install and maintain an instructional innovation. Lim and Khine (2006 p.97 and 120) reinforced the importance of the support environment. In their study the teachers referenced to Information and Communications Technologies (ICT) integration to be the lack of access to computers, inadequate technical support and lack of support from peers and inadequate numbers of computers. Training, education and technical support can affect the way an individual applies a technology in a useful way and/or finds it easy to use (Venkatesh, 1999, p.253).

\subsection{Subjective Norm}

Fishbein and Ajzen (1975, p.16 and 301) defined SN as a person's perception that most people who are important to that person think whether the behaviour in question should or should not be performed by the person. In an organizational setting, it is possible to trace back the concept of 'important people' to the supervisor and the referent group (Teo et al., 2008 p.131). This means that, $\mathrm{SN}$ is the degree to which an individual perceives the demands of others on that individual's behaviour. In their study Venkatesh and Davis (2000 p.197) completely assumed this argument in the technology acceptance concept. They claimed that when a co-worker thought the system was useful, a person tended to have the same idea. Individuals can choose to perform a specific behaviour even if they are not positive towards the behaviour or its consequences. SN was found as a strong determinant to behavioral intention, and to a wide range of social behaviors (Fishbein and Ajzen 1975, p.328). SN has been empirically tested and has had a significant direct (Mathieson 1991 p.184-185; Taylor and Todd 1995 p.163-164) or indirect effect (Venkatesh and Davis 2000 p.195) in predicting an individual's IU computer technology. Ballone 
and Czerniak (2001 p.24) informed students' positive opinions of the instructor increased in proportion to the use of the computers in the class- room. Marcinkiewicz and Regstad (1996 p.27) conducted a study that directly examined the influence of $\mathrm{SN}$ on computer use. They reported that $\mathrm{SN}$ is most predictive of computer use, beside self-competence, perceived relevance and perceived innovativeness. Lucas and Spitler (1999 p.291) and Venkatesh and Davis (2000 p.197) also reported that organizational variables such as social norms are more important than user's perceptions of IT in predicting system usage and acceptance.

\section{RESEARCH MODEL AND HYPOTHESES}

While taking TAM as the core model, SN and FC were introduced to form a composite model to explore academicians' acceptance of IT. The direct and indirect effects of each construct constituted the hypotheses (Figure 1) and were tested through empirical data. Formulation of each hypothesis is described as follows.

Figure 1: Research Model

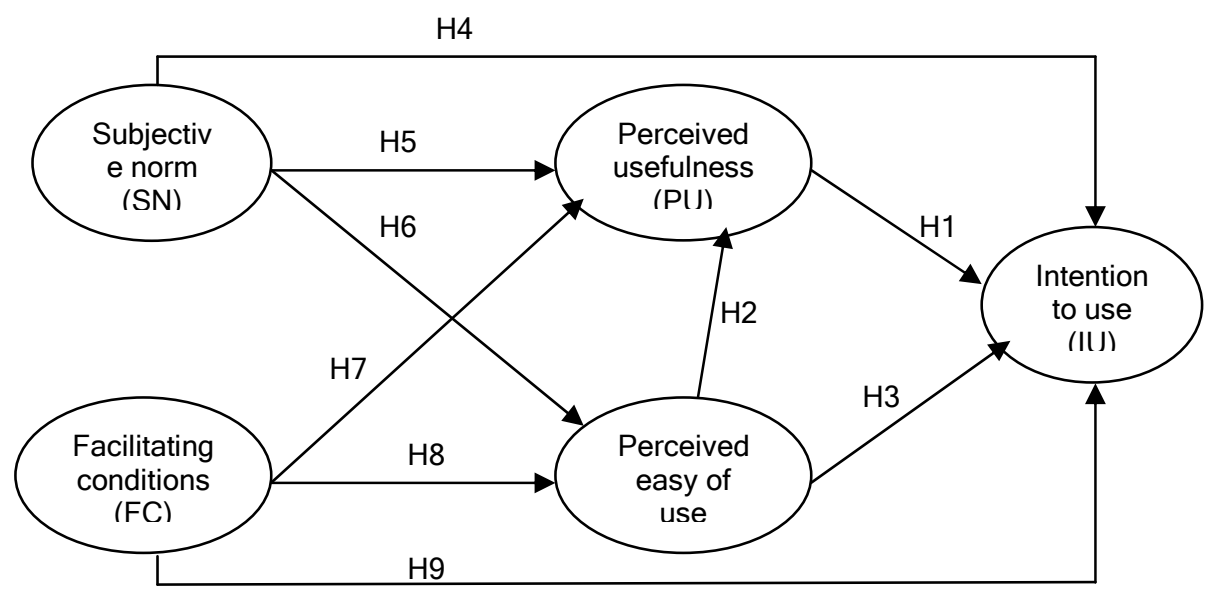

\subsection{Traditional TAM Hypotheses}

The TAM suggests that two factors PEOU and PU are the two main factors in explaining system use. PU is defined as the prospective users' subjective probability that using a specific application system will increase his or her job performance within an organizational context (Davis et al., 1989 p.985). This factor has a significant effect on usage intention (Agarwal and Prasad, 1999 p.377; Davis et al., 1989 p.997; Venkatesh, 2000, p.357; Venkatesh and Davis, 2000 p.197). PEOU is defined as the degree to which the prospective user expects the target system to be free of effort (Davis et al., 1989 p.985). This 
factor plays a crucial role in understanding individual response to IT (Agarwal and Karahanna, 2000 p.683; Chau and Hu , 2001 p.709; Hong et al., 2001 p.115). Research over the past decade provides evidence of the significant effect PEOU has on usage intention (Agarwal and Prasad, 1999, p.377; Venkatesh, 2000, p.357; Venkatesh and Davis, 2000 p.197). If academicians subjectively thought that IT would help their job performance in any way, it would be a motivation for them to tend to use IT. Therefore, we posited that,

H1: An academician's PU of IT would positively influence his or her IU IT.

Then again, even if an academician thought that IT was useful, he or she might at the same time believe that the system was too difficult to use and that the performance benefits of usage were outweighed by the effort of using IT (Davis 1989, p. 320). Hence It was expected that academician' PEOU of IT would have a direct effect on their IU IT. If academicians perceived IT as hard to use, it would be doubtful that IT could really improve their job performance. That is, it would also affect their subjective evaluation of the usefulness of IT. Therefore, we suggested that,

H2: An academician's PEOU of IT would positively influence his or her PU of IT.

H3: An academician's PEOU of IT would positively influence his or her IU IT.

\subsection{The Influence of Subjective Norm}

Some studies reported that organizational variables such as social norms are more important than user's perceptions of IT in predicting system acceptance and usage (Lucas and Spitler, 1999 p.304 and Venkatesh and Davis, 2000 p.197). Thus, the social normative component captures the collective effect of these influences on behavioral intention.

H4: An academician's SN perception related to IT use would positively influence his or her IU IT.

In our current study, we were tended to the viewpoint that academicians were close and would be influenced by the thinking of important others both in making their decisions regarding IT acceptance, and in evaluating IT as useful. Therefore, we posited that,

H5: An academician's SN perception related to IT use would positively influence his or her PU of IT.

The academician perceives the important others would think he or she should use IT. He or she would also have a general perception that, as the important others think that he or she should use IT it must be easy to use. Therefore, we proposed that, 
H6: An academician's perception on SN has a positive effect on his or her PEOU about IT.

\subsection{The Influence of Facilitating Conditions}

Training, education and technical support can affect the way an individual applies a technology in a useful way and/or finds it easy to use (Venkatesh, 1999, p.253). Giving hands on sessions and feedback can illustrate functions and features of a technology, thus influencing PU. Furthermore, generally, if somebody demonstrates a technology it is perceived easier to use then if an individual has to learn it by him. Hence, we hypothesized:

H7. An academician's perception of FC related to IT use would positively influence his or her PU of IT.

H8. An academician's perception of FC related to IT use would positively influence on his or her PEOU of IT.

H9: An academician's perception of FC related to IT use would positively influence his or her IU toward IT.

\section{METHODOLOGY}

\subsection{Questionnaire}

To examine academicians' acceptances towards ITs with the extended TAM, a questionnaire including 24 items in two parts were designed: 17 questions related to the constructs in the research model; 7 items related to the demographic data. Five questions in PU construct were taken from Davis (1989, p.331), and Chin and Todd (1995 p.244-245) while that four items in PEOU construct were taken from Davis (1989, p.331), and Adams et al. (1992 p.237). Three questions in IU construct were taken from Ajzen and Fishbein (1980, p.42 and 104). Two items in SN scale were taken from Taylor and Todd (1995 p.174).Three items in FC construct were taken from Thompson et al. (1991 p. 132) (see Table 1). Because of the general tendency of using and its simplicity, A Likert-type scale ranging from 1 (strongly disagree) to 5 (strongly agree) were preferred for measuring 14 items in the constructs of the model. The constructs, sources of the constructs, and items are summarized in Table 1. 
Table 1: Constructs, Items and Sources

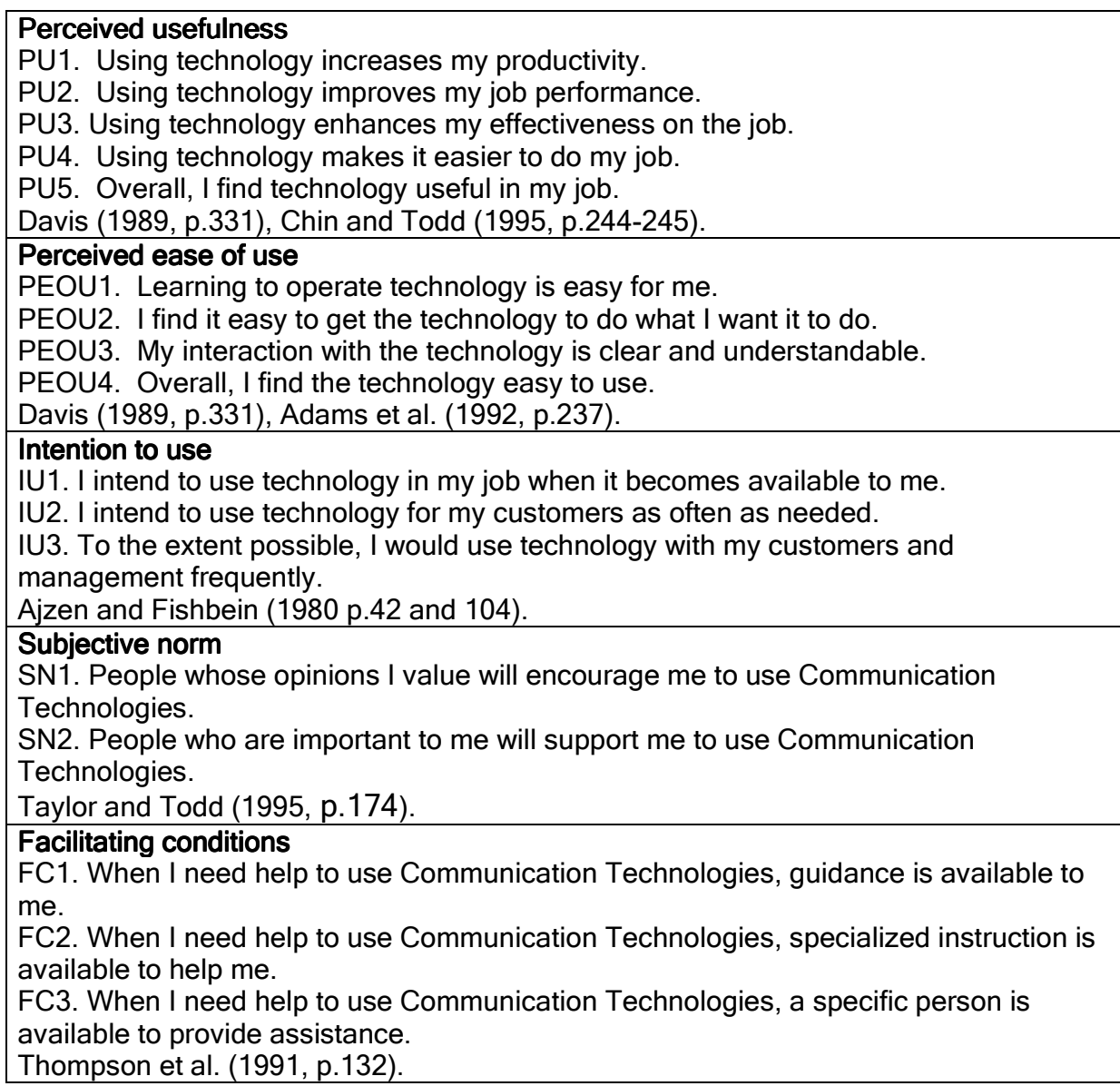

\subsection{Sampling and Participants}

At the research time, there were 94 state and 31 foundation universities in Turkey. Survey was designed as a web page link based. Questionnaires were sent to the academicians working in 7 state universities, that were 15 years old and up, randomly chosen from 7 regions in Turkey. And also these state universities were the ones that we had been able to reach the e-mails of their academicians. Questionnaires were sent to all academicians in every department at these universities and completed anonymously. Numbers of academicians sent e-mail were 5814. Response rate was $8.77 \%$ with a valid number of 510 academicians, including instructors, lecturers, research assistants, and professors. Demographic data percentages related to the gender, age, academic title and academic units are given in Table 2. 
Table 2: Demographic Valid Percents (N=510)

\begin{tabular}{|l|c|l|c|l|c|l|r|}
\hline Gender & $\%$ & \multicolumn{1}{|c|}{ Age } & $\%$ & Academic Title & $\%$ & $\begin{array}{c}\text { Academic } \\
\text { Units }\end{array}$ & $\%$ \\
\hline Female & 49.7 & $\begin{array}{l}30 \text { and } \\
\text { below }\end{array}$ & 23.8 & Professor Dr. & 14.6 & Institutes & 5.1 \\
\hline Male & 50.3 & $31-40$ & 38.6 & $\begin{array}{l}\text { Associate Prof. } \\
\text { Dr. }\end{array}$ & 13.0 & Faculties & 75.9 \\
\hline & $41-50$ & 22.5 & $\begin{array}{l}\text { Assistant Prof. } \\
\text { Dr }\end{array}$ & 19.8 & Schools & 8.3 \\
\hline & $51-60$ & 11.2 & Instructor & 21.5 & $\begin{array}{l}\text { Vocational } \\
\text { schools }\end{array}$ & 7.9 \\
\hline & 61 and up & 3.9 & Lecturer & 2.6 & $\begin{array}{l}\text { Research } \\
\text { centers }\end{array}$ & 1.2 \\
\hline & & & $\begin{array}{l}\text { Research } \\
\text { assistant }\end{array}$ & 25.9 & Others & 1.6 \\
\hline & & & Expert & 2.6 & & \\
\hline
\end{tabular}

\subsection{Research Analyses}

For questionnaire scales, an explanatory factor analyses (Kaiser-Meyer- Olkin and Barlett's Test, Maximum Likelihood and Direct Oblimin Rotation Method) were performed. Cronbach's alpha reliability analyze was performed to assess the reliability of the latent variables in the research model. "If item deleted" method was also used in analyses for items of the constructs. Overall measurement quality was determined using CFA (Gerbing and Anderson 1988 p.187). Structural Equation Modelling was used to test assumed hypotheses.

\section{FINDINGS}

The values of the sampling adequacy for PU, PEOU, IU SN and FC were acceptable. Kaiser-Meyer- Olkin (KMO) test value was 0,914 . Significance values for Barlett's test of sphericity approved reliability $(p=0.000)$. Measures of Sampling Adequacy (MSA) values were between 0.77 and 0.97 . Results of the factor analysis with Maximum Likelihood and Direct Oblimin Rotation Methods confirmed the research data. The calculation values of Cronbach's alpha for each of the constructs used were found greater than the acceptable limit (Cronbach's alphas $\geq 0.88$ ). These analyses showed that all data values of results were determined suitable for, and included into the further tests. The reliabilities, means, standard deviations and spearman correlation coefficients for the scales are presented in Table 3. 
Table 3: Reliabilities, Scales Means, Standard Deviations and Spearman Correlations

\begin{tabular}{|c|c|c|c|c|c|c|c|c|}
\hline $\begin{array}{l}\text { Construct } \\
\text { [number of items] }\end{array}$ & $\begin{array}{l}\text { Croanbach's } \\
\text { Alpha** }^{* *}\end{array}$ & Mean & SD & 1 & 2 & 3 & 4 & 5 \\
\hline $\begin{array}{l}\text { 1. Perceived } \\
\text { usefulness (PU) } \\
\text { [5] }\end{array}$ & 0.95 & 4.59 & 0.73 & 1 & & & & \\
\hline $\begin{array}{l}\text { 2. Perceived } \\
\text { ease of use } \\
\text { (PEOU) }[4]\end{array}$ & 0.89 & 4.05 & 0.79 & $0.453^{*}$ & 1 & & & \\
\hline $\begin{array}{l}\text { 3. Intention to } \\
\text { use (IU) [3] }\end{array}$ & 0.90 & 4.45 & 0.72 & $0.604^{*}$ & $0.698^{*}$ & 1 & & \\
\hline $\begin{array}{l}\text { 4. Subjective } \\
\text { norm (SN) [2] }\end{array}$ & 0.88 & 3.69 & 0.96 & $0.267^{*}$ & $0.413^{*}$ & $0.336^{*}$ & 1 & \\
\hline $\begin{array}{l}\text { 5. Facilitating } \\
\text { Conditions (FC) } \\
\text { [3] }\end{array}$ & 0.92 & 3.14 & 1.04 & $0.278^{*}$ & 0.054 & 0.164 & $0.414^{*}$ & 1 \\
\hline
\end{tabular}

${ }^{*} \mathrm{p}<0.01{ }^{* *}$ Value with only 2 items represents correlation; values with more than 2 items represent Cronbach's alphas.

\subsection{Measurement Model}

After exploratory data analyses, a confirmatory factor analysis (CFA) using Lisrel software were performed to find out overall measurement quality of the research model. CFA results approved the outputs of the exploratory analyses. The measurement model had a Chi-square of $249.81(p=0,000)$ with 105 degrees of freedom (df). The ratio of chi-square/df of the measurement model was 2.38. The root mean square error of approximation (RMSEA) of the measurement model was 0,052 , and the root mean square residual (RMSR) was 0,030, indicating an acceptable fit (Hooper et al., 2008, p.53-56; Reisinger and Mavondo, 2006, p.56-57). Overall, the measurement model indicated an acceptable fit with a normed fit index (NFI) of 0.98 , and a comparative fit index (CFI) of 0.99 (Hu and Bentler, 1999, p.27-28). The goodness-of-fit index (GFI) is 0.95 , the adjusted goodness-of-fit index (AGFI) is 0.92 , and the parsimony normed fit index (PNFI) is 0.76 . CFA results confirmed the overall measurement quality of the research model (Gerbing and Anderson 1988, p.187).

\subsection{Research Model}

The research hypotheses related to the structural equation model were tested using Lisrel software. The findings of the structural equation model presented in Figure 2 (also see Figure 1) showed an acceptable fit of the data; the resulting Chi-square is 414.32 with 109 degrees of freedom (Chi-square/df $=3,80, p<$ 0.000, RMSEA $=0.074, \mathrm{RMSR}=0.033, \mathrm{GFI}=0.91$, AGFI $=0.88, \mathrm{NFI}=0.98$, CFI=0.98) (Hooper et al., 2008, p.53-56). 
Standardized path coefficients and their corresponding t-values and results related to the research model hypotheses were given in the Table 4 (also see Figure 2).

$\mathrm{H} 1$ suggested that an academician's PU would directly influence his or her IU and standardized path coefficient supports this hypothesis $(p<0.01)$ (See Figure 2 and Table 4).

Hypothesis $\mathrm{H} 2$ predicted that PEOU has a positive affect on PU. As expected, path coefficient for PU was statistically significant $(p<0.01)$ and this hypothesis was accepted (See Figure 2 and Table 4).

H3 involved that an academician's PEOU would directly influence his or her IU. Since the path coefficient between PEOU and IU constructs was statistically significant $(p<0.01)$ (See Figure 2 and Table 4), H3 hypothesis was accepted.

$\mathrm{H} 4$ suggested that $\mathrm{SN}$ is positively related to IU. Since the path coefficient between $\mathrm{SN}$ and IU constructs was statistically significant $(p<0.01), \mathrm{H} 4$ hypothesis was accepted (See Figure 2 and Table 4).

Figure 2: The Research Model

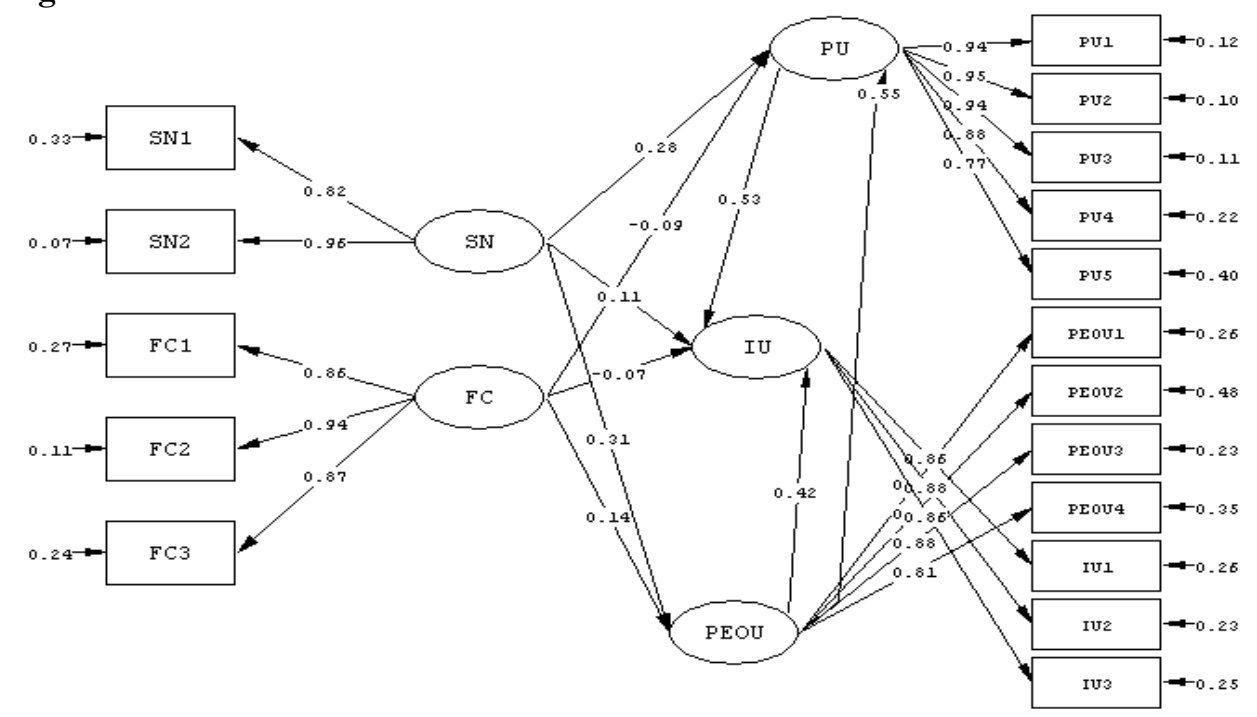

Chi-Square=414.32, df=109, F-value=0.00000, RMSEA=0.074

H5 supposed that SN positively affects PU. As expected, path coefficient between $\mathrm{SN}$ and $\mathrm{PU}$ was statistically significant at the 0.01 level, and this hypothesis was accepted (See Figure 2 and Table 4).

$\mathrm{H} 6$ suggested that SN has a positive affect on PEOU and standardized path coefficient supports this hypothesis $(p<0.01)$ (See Figure 2 and Table 4). 
Table 4: Results of Hypothesis Tests

\begin{tabular}{|c|c|c|c|c|}
\hline \multicolumn{2}{|c|}{ Hypothesized Paths } & \multirow{2}{*}{$\begin{array}{c}\text { t } \\
\text { Values } \\
13.02^{*}\end{array}$} & \multirow{2}{*}{$\begin{array}{l}\text { Standardized } \\
\text { Path Coeffic. } \\
0.53\end{array}$} & \multirow{2}{*}{$\begin{array}{l}\text { Results } \\
\text { Supported }\end{array}$} \\
\hline $\mathrm{H} 1$ & $\begin{array}{l}\text { Perceived usefulness (PU) - Intention } \\
\text { to use (IU) }\end{array}$ & & & \\
\hline $\mathrm{H} 2$ & $\begin{array}{l}\text { Perceived ease of use (PEOU) - } \\
\text { Perceived usefulness (PU) }\end{array}$ & $12.44^{*}$ & 0.55 & Supported \\
\hline H3 & $\begin{array}{l}\text { Perceived ease of use (PEOU) - } \\
\text { Intention to use (IU) }\end{array}$ & $10.34^{*}$ & 0.42 & Supported \\
\hline $\mathrm{H} 4$ & $\begin{array}{l}\text { Subjective norm (SN) - Intention to } \\
\text { use (IU) }\end{array}$ & $3.04^{*}$ & 0.11 & Supported \\
\hline $\mathrm{H} 5$ & $\begin{array}{l}\text { Subjective norm (SN) - Perceived } \\
\text { usefulness (PU) }\end{array}$ & $6.19^{*}$ & 0.28 & Supported \\
\hline $\mathrm{H} 6$ & $\begin{array}{l}\text { Subjective norm (SN) - Perceived } \\
\text { ease of use (PEOU) }\end{array}$ & $5.69^{*}$ & 0.31 & Supported \\
\hline $\mathrm{H} 7$ & $\begin{array}{l}\text { Facilitating conditions (FC) - } \\
\text { Perceived usefulness (PU) }\end{array}$ & $-2.19^{* *}$ & -0.09 & Not supported \\
\hline $\mathrm{H} 8$ & $\begin{array}{l}\text { Facilitating conditions (FC) - } \\
\text { Perceived ease of use (PEOU) }\end{array}$ & $2.71^{*}$ & 0.14 & Supported \\
\hline $\mathrm{H} 9$ & $\begin{array}{l}\text { Facilitating conditions (FC) - Intention } \\
\text { to use (IU) }\end{array}$ & $-2.28^{*}$ & -0.07 & Not supported \\
\hline
\end{tabular}

Hypothesis $\mathrm{H} 7$ predicted that $\mathrm{FC}$ was positively related to PU. The path coefficient related to $\mathrm{H} 7$ was statistically significant $(p<0.05)$, but this significantly relationship had been negatively, as not expected. And this hypothesis was rejected.

$\mathrm{H} 8$ involved that FC directly and positively influence an academician's PEOU. This hypothesized effect of FC on PEOU was supported by the data $(p<0.01)$ so that $\mathrm{H} 8$ hypothesis was accepted (See Figure 2 and Table 4).

H9 supposed that FC positively affects IU. Path coefficient between FC and IU was statistically significant, but negatively. And this hypothesis was rejected (See Figure 2 and Table 4).

\subsection{Modified Research Model}

In the hypothesized research model, hypotheses $\mathrm{H} 7$ and $\mathrm{H} 9$ were rejected. In spite of FC had significantly impacts on PU and IU, these effects were negatively instead of positively as expected. These results do not seem consistent to the logic. After the modification of error covariance, these effects of FC on PU and IU were insignificantly with $T$ values of -1.71 and -1.64 . Hence these relations were crossed out from the hypothesized research model and a modified research model was designed for recalculation (See Figure 3 and Figure 4). 
Figure 3: The Modified Research Model

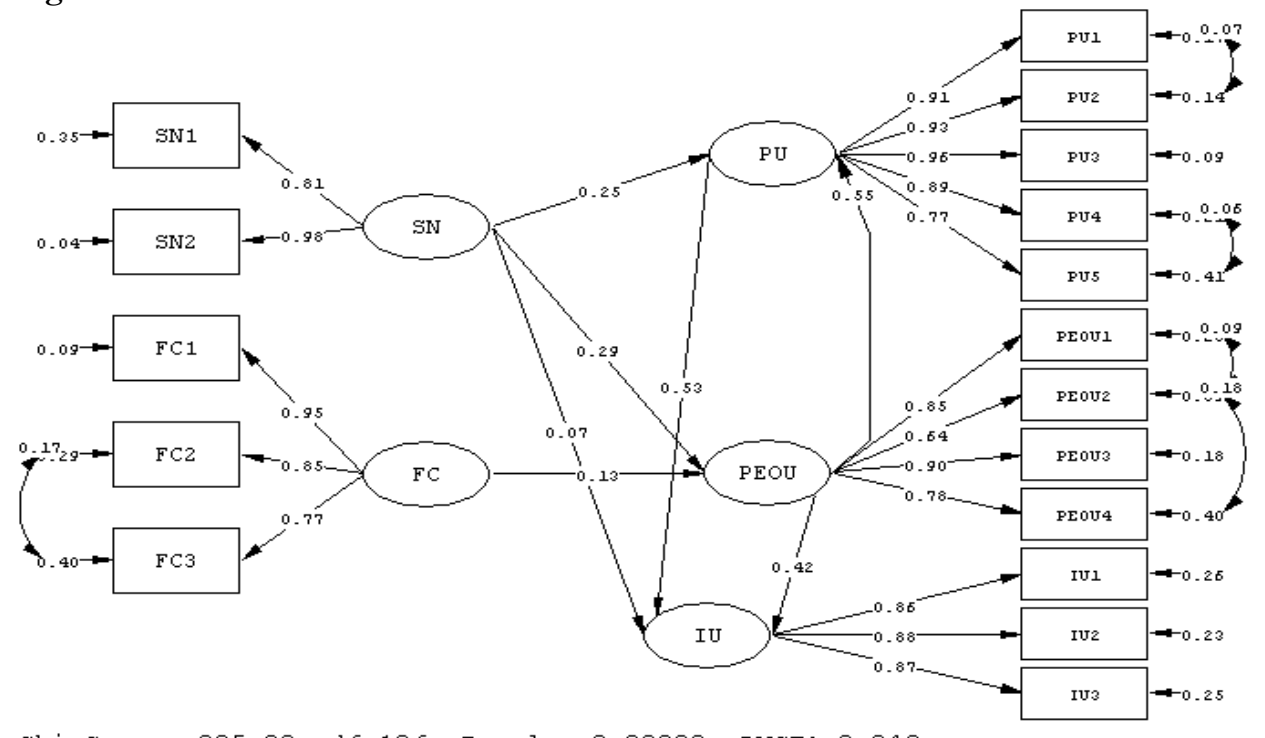

Chi-gquare=23.5.38, df=106, F-value=0.00000, FMsEA=0.049

Figure 4: The Modified Model Test Results

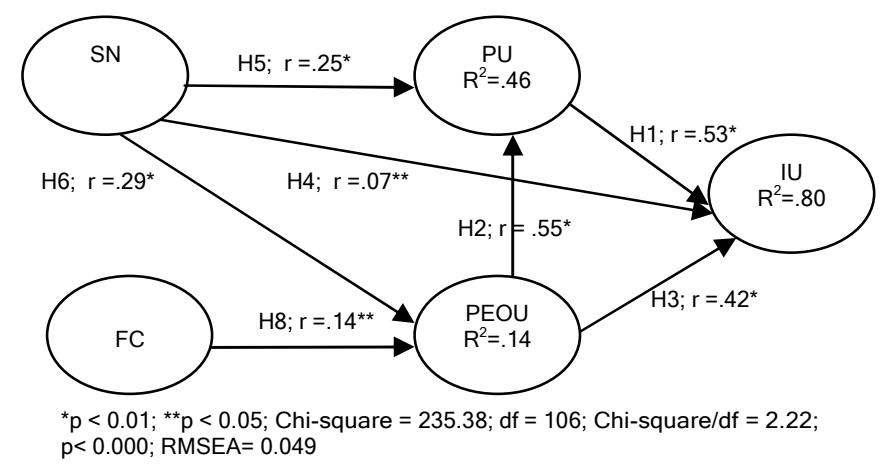

After modification, new structural research model was reanalyzed with Lisrel software. Results of this analysis presented an acceptable fit of data. The modified model had a Chi-square of $235.38(p=0.000)$ with 106 degrees of freedom (df). The ratio of chi-square/df of the measurement model was 2.22. The root mean square error of approximation (RMSEA) of the measurement model was 0.049 , and the root mean square residual (RMSR) was 0.035, indicating an acceptable fit $(\mathrm{GFI}=0.95, \mathrm{AGFI}=0.93, \mathrm{NFI}=0.99, \mathrm{CFI}=0.99)$ (see Figure 3, Figure 4 and Table 5).

The results of the structural equational model analyses are shown in Table 5, Figure 3 and Figure 4 . All of the path coefficients obtained from these analyses 
were statistically significant $\left({ }^{*} p<0.01\right.$ and $\left.{ }^{* *} p<0.05\right)$. These results of the modified model analyses also showed that $\mathrm{SN}$ and $\mathrm{FC}$ explained significantly $14 \%$ of the variance of PEOU. SN and FC had a direct effect on PEOU. SN and PEOU had a direct impact on PU and explained $46 \%$ of the variance of PU. PEOU also mediated a relationship between $\mathrm{SN}$ and PU. $80 \%$ of the variance of IU was explained by SN, PEOU and PU. SN showed a mediating impact on IU through PEOU and PU. FC also had a mediating effect on IU through PEOU.

Table 5: The Results of the Analysis of the Modified Model

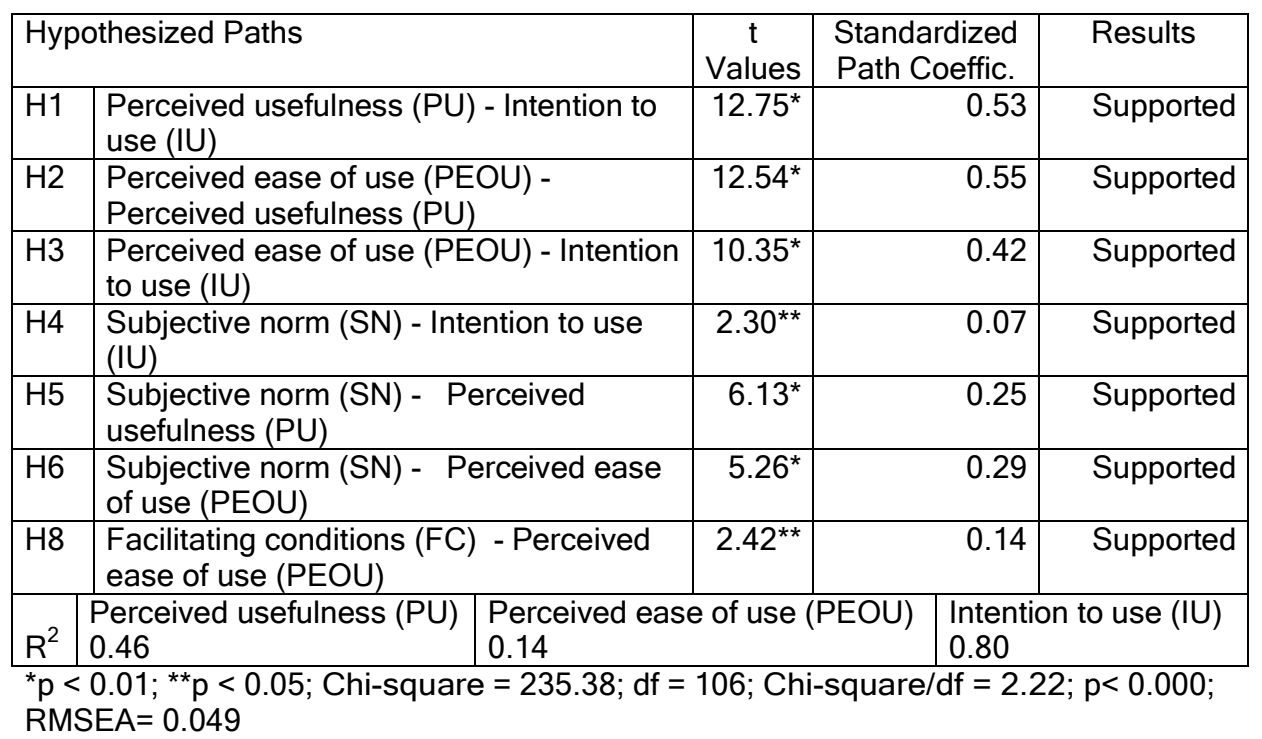

\section{DISCUSSION AND CONCLUSIONS}

With increasing global competition, IT literacy has become a key factor for both occupational and personal successes. An individual's technology acceptance is a crucial factor in determining the success or failure of a computer systems project. Given that the academician is the key to effective use of information technologies in the university educational system, it is important to understand academicians' IU towards IT and the factors that influence these intentions. Examining SN and FC of academicians could answer some questions relating to acceptance and usage of technology in teaching, learning and their academic studies. The purpose of this study is to examine academicians' acceptances towards ITs. This study extends the technology acceptance model (TAM) framework, with $\mathrm{SN}$ and $\mathrm{FC}$ acting as external variables.

Seven of the nine hypotheses of the initial research model were approved by data. $\mathrm{H} 7$ and $\mathrm{H} 9$ were rejected: $\mathrm{FC}$ had significantly but negatively effect on PU and IU; these results were not in the directions of expectations. This output also 
does not seem appropriate to the common sense. After modification, these relationships were insignificantly, and were crossed out from the hypothesized research model and a modified research model was designed for reanalyzing. The values of goodness-of-fit for modified structural equation model improved.

As expected, PU has a direct influence on IU. This result is consistent to the prior researches (Agarwal and Prasad, 1999, p.377; Davis et al., 1989, p.330; Venkatesh, 2000, p.357; Venkatesh and Davis, 2000, p.197).

PEOU showed a significant influence on an academician's IU IT. This direct relationship between PEOU and IU was consistent to the previous studies (Agarwal and Karahanna, 2000, p.683; Agarwal and Prasad, 1999, p.377; Chau et. al. 2001, p.709; Hong et al., 2001, p.115; Venkatesh, 2000 p.357; Venkatesh and Davis, 2000, p.197).

PEOU had a direct positive affect on PU, and also PEOU had a mediating impact on IU through PU. This result impacts that the easier the use of IT is perceived to be, the more likely academicians will perceive their usefulness. These findings approved the earlier studies (Agarwal and Prasad, 1999, p.377; Burton-Jones and Hubona, 2006, p.712; Davis et al., 1992, p.330 and Shang et al., 2005, p.408). These direct and mediating impacts of PEOU and PU on IU strengthened IU, and this situation was a consistent result to the TAM model (Taylor and Todd, 1995; Schillewaert et al, 2005, p.325).

Among the variables within the TAM, PU, rather than PEOU, had a greater effect on IU. But PEOU additionally had a fortified mediating effect on IU via PU. SN had a significant direct influence on PU, PEOU and IU, and mediating effect on IU through PU and PEOU. These results were consistent to the previous studies (Mathieson 1991, p.184-185; Taylor and Todd 1995, 168-170; Venkatesh and Davis 2000, p.197) in predicting an individual's IU technology. The direct impact of SN on IU was lower than the ones on PEOU and PU. This showed that the mediating effects of $\mathrm{SN}$ were considerable.

FC indicated a direct influence on PEOU. This results support the previous studies related to FC, PEOU and IU (Frambach and Schillewaert, 2002, p.167; Groves and Zemel, 2000, p.57; Schillewaert et al., 2005, p.325; Venkatesh, 1999, p.253).

As not expected, FC did not had any impact on PU and IU. This result did not support the prior studies on the subject of FC, PU and IU (Groves and Zemel, 2000, p.57; Daughtery and Funke, 1998, p.37-38; Farquhar and Surry, 1994, p.22; Lim and Khine, 2006, p.120). Nonetheless FC had a mediating effect on IU through PEOU.

Our study attempted to build up an extended TAM model with the traits of SN and FC in order to investigate the acceptance of IT from the view point of academicians in the one of the countries of Turkish World. 
It can be said that this extended model, if you compare with the results of literature (Legris et al., 2003, p.191,200 and 201), is highly successful in explaining IU IT with the rate of 0.80 . This study showed that the core TAM relations resulted in just as well in a Turkish environment as they did in Western countries. On the other hand, the model approved that $\mathrm{SN}$ made a valuable contribution in explaining of the variances of TAM. FC also backed the model but at the lower level than SN. These findings demonstrated that SN and FC are potential variables that may be used to extend the TAM for research on IU towards IT. But the highly low value for the PEOU with 0.14 indicates that it needs to be taken into account by the researchers and educational managers in order to increase this explaining rate finding out the new indicators affecting the factors of this extended model. The means of PU, PEOU, IU of the academicians are generally high and very high $(X>4.05)$. But these means are weak for SN and FC with 3.69 and 3.14 respectively. These results indicate that the variable to be taken into account firstly is FC (support from management).

One of the limitations of this study is the sample being drawn just only from the State Universities being fifteen years or more. Another limitation is that the state universities in the research had been drawn from the ones that we had been able to reach the e-mails of their academicians. For future research new established and foundation universities also should be included into the sample, and it should be taken into account individual differences, and other stakeholders such as managers, students, employers and investors. This research should be repeated for diverse cultures and sectors to be able to have more reliable results related to the validity of model.

This research showed that managers should strategize academicians to meet better $\mathrm{FC}$ and $\mathrm{SN}$, and work with the co-workers pioneering in the subject of IU IT to be able to increase their employees' levels of technology acceptance. This study reveals that educational managers can use this research model as a helpful tool in better understanding stakeholders' behaviors towards technology acceptance and additionally they should also consider deeply investigating each of the variables in the technology acceptance process one by one.

\section{REFERENCES}

Adams, D.A., Nelson, R.R. and Todd, P.A. (1992), "Perceived usefulness, ease of use, and usage of information", MIS Quarterly, 16, 2, pp. 227-247.

Agarwal, R. and Karahanna, E. (2000), "Time flies when you're having fun: cognitive absorption and beliefs about information technology usage", MIS Quarterly, 24, 4, pp. 665-694.

Agarwal, R. and Prasad, J. (1999), "Are individual differences germane to the acceptance of new information technologies?", Decision Sciences, 30, 2, pp. 361-391. 
Ajzen, I. and Fishbein, M. (1980), "Understanding Attitudes and Predicting Social Behavior", Prentice Hall, Englewood Cliffs.

Ajzen, I. (1991), "The theory of planned behavior", Organizational Behavior and Human Decision Processes, 50, 2, pp. 179-211.

Ballone,L.M. and Czerniak, C.M. (2001), "Teachers' beliefs about accommodating students' learning styles in Science classes", Electronic Journal of Science Education, 6, 2, pp.1-41.

Bannan-Ritland, B., Dabbagh, N., and Murphy, K. (2000), "Learning object systems as constructivist learning environments: related assumptions, theories, and applications", available at: http:// www.reusability.org/read/chapters/bannan-ritland.doc (accessed 11 May 2010).

Bielaczyc, Katerine (2006), "Designing social infrastructure: Critical issues in creating learning environments with technology", Journal of the Learning Sciences, 15, 3, pp.301-329.

Bratina, T.A., Hayes, D., and Blumsack, S.L. (2002), "Preparing teachers to use learning objects", $\quad$ available use_learning_objects/(accessed 11 May 2010).

Breen, R, Lindsay, R., Jenkins, A. and Smith P. (2001), "The role of information and communication technologies in a university learning environment", Studies in Higher Education, 26, 1. pp. 95-114.

Burton-Jones, A. and Hubona, G.S. (2006), "The Mediation of external variables in the technology acceptance model", Information \& Management, 43, 6, pp. 706-717.

Chau, P.Y.K. and Hu, P.J.H. (2001), "Information technology acceptance by individual professionals: a model comparison approach", Decision Sciences, 32 4, pp. 699-719.

Cheney, P.H. and Dickson, G.W. (1982), "Organizational characteristics and information systems: an exploratory investigation", Academy of Management Journal, 25, 1, pp. 170-184.

Chin, W.W. and Todd, P.A. (1995), "On the use, usefulness, and ease of use of structural equation modelling in MIS research: a note of caution", MIS Quarterly, 19, 2, pp. 237-246.

Daughtery, M. and Funke, B.L. (1998), "University faculty and student perceptions of web-based instruction", Journal of Distance Education, 13, 1, pp. 21-39. 
Davis, F.D., Bagozzi, R.P., and Warshaw, P.R. (1989), "User acceptance of computer technology: A comparison of two theoretical models", Management Science, 35, 8, pp. 982-1003.

Davis, F.D. (1989), "Perceived usefulness, perceived ease of use, and user acceptance of information technology", MIS Quarterly, 13, 3, pp. 319-339.

Davis, F.D., Bagozzi, R.P., and Warshaw, P.R. (1992), "Extrinsic and intrinsic motivation to use computers in the workplace" Journal of Applied Social Psychology, 22, 1, pp. 1111-1132.

Davis, F.D. (1993), "User acceptance of information technology: System characteristics, user perceptions and behavioral impacts" International Journal of Man-Machine Studies, 38, 3, pp. 475-487.

Doll, W.J., Hendrickson, A., and Deng, X. (1998), “Using Davis's perceived usefulness and ease-of-use instruments for decision making: a confirmatory and multi-group invariance analysis", Decision Sciences, 29, 4, pp. 839-869.

Farquhar, J.D. and Surry, D.W. (1994), "Adoption analysis: an additional tool for instructional developers", Education and Training Technology International, 31, 1, pp. 19-25.

Fishbein, M., and Ajzen, I. (1975), "Belief, Attitude, Intention, and Behavior: An Introduction to Theory and Research", Addison-Wesley, Reading, Boston.

Frambach, R.T. and Schillewaert, N. (2002), "Organizational innovation adoption: a multi-level framework of determinants and opportunities for future research", Journal of Business Research, 55, 2, pp. 163-176.

Gerbing, David W. and James C. Anderson (1988). "An updated paradigm for scale development incorporating unidimensionality and its assessment". Journal of Marketing Research. 25 (2): 186-192.

Groves, M.M. and Zemel, P.C. (2000), "Instructional technology adoption in higher education: an action research case study", International Journal of Instructional Media, 27, 1, pp. 57-65.

Hong, W., Thong, J.Y.L., Wong, W.M. and Tam, K.Y. (2001), "Determinants of user acceptance of digital libraries: an empirical examination of individual differences and system characteristics", Journal of Management Information Systems, 18, 3, pp. 97-124.

Hooper, D. Coughlan, J. and Mullen, M. R. (2008), "Structural equation modelling: guidelines for determining model fit", The Electronic Journal of Business Research Methods, 6, 1, pp.53-60, available at http://www.ejbrm.com/vol6/v6-i1/v6-i1-papers.htm, (accessed 10 May 2009). 
$\mathrm{Hu}$, Li-tze. and Peter M. Bentler (1999). Cutoff criteria for fit indexes in covariance structure analysis: Conventional criteria versus new alternatives. Structural Equation Modeling, 6 (1), pp.1-55.

Legris P., Ingham, J., and Collerette, P. (2003), "Why do people use information technology? A critical review of the technology acceptance model", Information and Management, 40, 3, pp. 191-204.

Lim, C.P. and Khine, M.S. (2006), "Managing teachers' barriers to ICT integration in Singapore schools", Journal of Technology and Teacher Education, 14, 1, pp. 97-125.

Lu, J., Yao J.E., Yu, C-S. (2005), "Personal innovativeness, social influences and adoption of wireless Internet services via mobile technology", Journal of Strategic Information Systems, 14, 3, pp. 245-268.

Lucas, H.C. and Spitler, V.K. (1999), "Technology use and performance: a field study of broker workstations", Decisions Sciences, 30, 2, pp. 291-311.

Marcinkiewicz, H. R. and Regstad, N.G. (1996), "Using Subjective Norms To Predict Teachers' Computer Use", Journal of Computing in Teacher Education, 13, 1, pp. 27-33.

Marriott, N, Marriott, P. and Selwyn, N. (2004). "Accounting undergraduates changing use of ICT and their views on using the Internet in higher education", Accounting Education, 13, 1, pp.117-130.

Martinez-Torres M.R., Marin, S.L.T., Garcia F.B., Vazquez S.G., Oliva M.A. and Torres T. (2008), "A technological acceptance of e-learning tools used in practical and laboratory teaching, according to the European higher education area", Behaviour \& Information Technology, 27, 6, pp.495-505.

Mathieson, K. (1991), "Predicting user intentions: Comparing the technology acceptance model with the theory of planned behaviour", Information Systems Research, 2, 3, pp.173-191.

McMahon, J., Gardner, J., Gray, C., and Mulhern, G. (1999), "Barriers to student computer usage: staff and student perceptions", Journal of Computer Assisted Learning, 15, 4, pp.302-311.

Mun, Y.Y. and Hwang, Y. (2003), "Predicting the use of web-based information systems: self-efficacy, enjoyment, learning goal orientation, and the technology acceptance model" International Journal of Human-Computer Studies, 59, 4, pp. 431-449.

Reffell, P.and Whitworth, A. (2002), "Information Fluency: Critically Examining IT Education”, New Library World, 103, 11-12, pp.427-435. 
Reisinger, Y. and Mavondo, F. (2006), "Structural Equation Modeling: Critical Issues and New Developments", Journal of Travel \& Tourism Marketing, 21, 4, pp. 41-71.

Selwyn, N. (2007), "The use of computer technology in university teaching and learning: a critical perspective", Journal of Computer Assisted Learning, 23, 2, pp. 83-94.

Schillewaert, N., Ahearne, M. J., Frambach, R. T., and Moenaert, R. K. (2005), "The adoption of information technology in the sales force", Industrial Marketing Management, 34, 4, pp. 323-336.

Segars, A.H. and Grover, V. (1993), "Re-examining PEOU and usefulness: a confirmatory factor analysis", MIS Quarterly, 17, 4, pp. 517-525.

Selwyn, N. (2007), "The use of computer technology in university teaching and learning: A critical perspective", Journal of Computer Assisted Learning, 23, 2, pp.83-94.

Shang, R.A., Chen, Y.C., and Shen, L. (2005), "Extrinsic versus intrinsic motivations for consumers to shop on-line", Information \& Management, 42, 3, pp. 401-413.

Taylor, S., and Todd, P.A. (1995), "Understanding information technology usage: a test of competing models", Information Systems Research, 6, 2, pp. $144-176$.

Teo, T., Lee, C.B., and Chai, C.S. (2008), "Understanding pre-service teachers' computer attitudes: applying and extending the technology acceptance model", Journal of Computer Assisted Learning, 24, 2, pp. 128-143.

Thompson, R.L., Higgins, C.A., and Howell, J.M. (1991), "Personal computing: toward a conceptual model of utilization", MIS Quarterly, 15, 1, pp. 124-143.

Turan, A.H. and Colakoglu, B.E. (2008), "Faculty's Acceptance And Use Of Technology In Higher Education: An Empirical Assessment At Adnan Menderes Universıty”, Dogus Universitesi Dergisi, 9, 1, pp.106-121.

Varol, E.S., Tarcan, E. and Ozmen, I. (2010), "The acceptance and use of elearning systems in Turkey", International Journal of Innovation and Learning, 8, 1, pp.90-105.

Venkatesh, V. (1999), "Creation of favourable user perceptions: exploring the role of intrinsic motivation", MIS Quarterly, 23, 2, pp. 239-260. 
Venkatesh, V. (2000), "Determinants of PEOU: integrating control, intrinsic motivation, and emotion into the technology acceptance model", Information Systems Research, 11, 4, pp. 342-365.

Venkatesh, V. and Davis, F.D. (2000), "A theoretical extension of the technology acceptance model: four longitudinal field studies", Management Science, 46, 2, pp. 186-204.

Venkatesh, V., Morris, M.G., Davis, G.B., and Davis, F.D. (2003), "User acceptance of information technology: toward a unified view", MIS Quarterly, 27, 3 , pp. 425-478.

Wiley, D. (2001), "Peer-to-peer and learning objects: the new potential for collaborative constructivist learning online", Paper presented at the Proceedings of the IEEE International Conference on Advanced Learning Technology, pp.494-495. 